\title{
Liability and Collective Identity: A Response to Walzer
}

\author{
Jeff McMahan
}

Published online: 4 August 2006

(C) Springer Science + Business Media B.V. 2006

There is much to admire in Michael Walzer's discussion of terrorism and just war. I particularly applaud his insistence that liability to attack is a matter of action rather than membership or collective identity. "It is," he writes, "the extension of violence or the threat of violence from individuals to groups that is the special feature of terrorism: Men and women are targeted because of their membership... It is who you are, not what you are doing, that makes you vulnerable; identity is liability. And that's a connection that we are morally bound to resist (Walzer, 2006)." This seems to me an important insight about the distinctive wrongness of terrorism - that its harming of the innocent is not only intended as a means of influencing the deliberation and action of others but is also a psychological assault against and a devaluing of an entire group, membership in which by the immediate victims is the sole basis of their selection as targets of attack. Walzer's insight also has significant implications for the requirement of discrimination in war.

Despite the article's great merits, I have two major reservations about its arguments. Both concern claims advanced in section 1. I also have doubts about the sharp distinction Walzer draws in section 3 between war and police action. I think that just war is police action of a sort while unjust war is criminal action of a sort. This is a significant disagreement but I will not pursue it here.

My most serious concern about Walzer's argument derives from his failure consistently to adhere to the rejection of group membership as a basis of liability to attack. Consider soldiers. Walzer embraces the accepted view that "it is entirely legitimate to kill soldiers at random, as they come within range, so to speak, and it is legitimate to try to terrorize the ones who never come within range (Walzer, 2006)." What is it about soldiers, once war has begun, that makes them "rightly subject to attack, all of them, all the time" (unless they have surrendered or been taken prisoner) (Walzer, 2006)? According to Walzer's view and here he speaks for the dominant tradition within just war theory - it is because they are "materially engaged in the war effort (Walzer, 2006)." They actively pose a threat to others, thereby rendering themselves liable to defensive killing. Their liability is a function of their action - their engagement in the business of war. 
Yet he concedes that not all soldiers are combatants. So he asks how those who do not seem to be materially engaged in fighting a war can be morally liable to attack. The answer he gives is that, when a country is at war, membership in its military necessarily involves contributing to its war effort. All the members of an army "contribute to the achievement of its ends. ... In time of war they pose a unified threat (Walzer, 2006)." To illustrate his point, he cites various characteristics that are supposed to distinguish soldiers from civilians: They are collectively organized and disciplined, trained in the use of weapons, isolated on bases, and provided for by the state. But suppose that an individual soldier has all of these characteristics. None of them entails that, in time of war, he makes a material contribution to the war. The members of a militia, by contrast, may have none of these characteristics and yet be unambiguously involved in fighting a war.

The fact is that a standing military organization has many goals, even in time of war. It may be true that each of its members contributes to at least one of its goals; but that does not mean that, when it is at war, each contributes to its prosecution of the war. Some pursue other goals that are entirely unrelated to the war. Some may even obstruct the prosecution of the war: For example, a military lawyer who, acting in fidelity to her understanding of the military's own guiding principles, seeks to revise the rules of engagement in a way that would hamper the effectiveness of military action in this instance.

It seems, therefore, that if all soldiers are liable to attack, their liability must be a matter of their membership in the military rather than a matter of what, as individuals, they are doing. So the view that any soldier who comes within range is a legitimate target seems vulnerable to the same objection that Walzer rightly urges against terrorism: It implies that individuals may be "targeted because of their membership." And if even in a just war it is a group - the military - that is the target and membership in the group is sufficient for liability, this tends in principle to collapse the distinction between just war and terrorism.

In practice, of course, it may not have this effect. As I noted in my first response to Walzer in this exchange, people often have to act on the basis of reasonable presumptions and especially on the battlefield it is a reasonable presumption that any enemy soldier who is not in the act of surrendering poses a threat. So this particular concern about Walzer's account of the liability of soldiers may be of comparatively little practical significance, however damaging it may be to the theoretical integrity of his view about the difference between terrorism and just war. Yet it is possible that circumstances may arise in which it makes a practical difference whether soldiers are liable to attack because of their membership or whether they are liable only because of what they do. Suppose our intelligence unit tells us that a group of enemy soldiers has arrived at the enemy base camp. In their home country these soldiers serve the military as accountants, lawyers, and physicians who deal with local tasks of no consequence to the war. They are stopping over in the war zone for only one night in order to visit friends. But the building in which they will be housed will be unguarded. We can send a team of commandos into their building to kill them in their sleep in the hope of terrorizing the active soldiers at the base. On Walzer's view as it is stated in his article, this would be permissible. On my view it would not be.

Next consider civilians. On Walzer's view, none are liable. His article seeks to answer certain questions: "Why are all civilians immune from attack [even when]... they share responsibility for immoral, possibly criminal, acts[?] Why aren't the terrorists right when they say that membership and responsibility make civilians collectively vulnerable to attack? (Walzer, 2006)" In part Walzer's answer is the traditional one: Civilians are innocent in the sense that they are not engaged in the prosecution of the war. Because they pose no threat, they cannot be the target of defensive force. Some have suggested that this point is 
beyond dispute, since it is in fact a conceptual truth that civilians do not materially contribute to the fighting of a war. Yet if this were true as a matter of definition, there would be fewer civilians than we think. For some people who are uncontroversially civilians do contribute, sometimes more significantly than most soldiers - for example, a scientist employed by a university whose research is financially supported by the Department of Defense because among its many possible applications are certain improvements in weapons technologies that can be used to great advantage in an ongoing war.

Walzer cites various characteristics of civilians that distinguish them from soldiers: They are not cohesively organized or disciplined, do not live in barracks, are of different ages, are not provided for by the government, and so on. These characteristics may indeed count against the claim that civilians may be collectively liable, which is the claim that Walzer explicitly attacks. But highlighting these characteristics does nothing to show that civilians cannot be individually liable because of their contributions to the prosecution of a war - yet the view that Walzer wishes to defend denies that civilians can be either collectively or individually liable. (Note that the view I defend in "The Ethics of Killing in War" implies that civilians may be individually liable - though not usually to military attack - not only if they materially contribute to the fighting of an unjust war but also if they are morally responsible for the initiation or continuation of an unjust war.)

It may be objected that my remarks here are off target, since what Walzer denies is that mere membership can be a basis of liability. But it is precisely his point that civilians are never liable. So what is my objection?

My objection is that if Walzer is right that mere membership cannot be a basis for the attribution of liability, it also cannot be a basis for the denial of liability. But Walzer makes membership in the civilian population a basis for the absence of liability. Liability and immunity are different sides of the same coin. To be morally immune to attack is just to be not morally liable to attack. So if, as Walzer plausibly claims, action and not membership is the basis of liability, then a person must be immune if he is not engaged in the relevant form of action. In short, if liability is a function of action and not membership, immunity must be a function of the absence of action and not of membership. But Walzer makes civilian status - that is, membership in the civilian collective - a guarantee of immunity. Although at the level of principle he asserts that membership is not a source of liability, his substantive claim is that membership in the military confers liability while membership in the civilian population confers immunity. In both instances, moral status is collectivized in a way that is independent of what individuals are actually doing. But this is, according to Walzer, the hallmark of terrorism.

There is, it seems to me, one other problem with Walzer's otherwise illuminating article, and again it has to do with the idea of immunity as a property of collectives rather than of individuals. Walzer contends that there are two dimensions to civilian or noncombatant immunity, one individual, the other collective. Civilians are immune as individuals and the civilian community is immune as a collective. "This," according to Walzer, "is the deepest meaning of noncombatant immunity: It doesn't only protect individual noncombatants; it also protects the group to which they belong (Walzer, 2006)."

This notion of collective immunity is different from the idea, which I claim is implicit in Walzer's argument, that civilians derive individual immunity from membership in the collective. Walzer's explicit notion of collective immunity is, rather, that the civilian collective as a whole is immune by virtue of what it is: A human community, an entity that has a right to exist over and above the rights to life of its individual members. Individual immunity signals the protected status of individual lives; collective immunity protects the survival of the individuals' "political or national community (Walzer, 2006)." 
Walzer thinks that recognition of the dual nature of noncombatant immunity is vital for understanding terrorism. If terrorism involves a violation of the immunity of the innocent, and there are two dimensions to this immunity, one individual and one collective, then terrorism may violate both. Walzer claims it does: "Terrorism attacks both these immunities (Walzer, 2006)."

The idea that terrorism necessarily violates the moral immunity of individuals is familiar. But the idea that terrorism also necessarily violates collective immunity is new. Here are the crucial passages in which this new idea is elucidated. "This is the wrong of terrorism: The murder of the innocent and the creation of a devalued collective, a group of men and women who have been deprived of the right to life or, alternatively, of the right to live where they are living (Walzer, 2006)." Terrorist acts, Walzer claims, "signal a political intention to destroy or remove or radically subordinate these people individually and this 'people' collectively (Walzer, 2006).'

As these passages make clear, Walzer holds that civilian or noncombatant immunity covers not only individual rights to life but the rights of civilian collectives to survival, habitation in the home territory, and political self-determination. And it is the "deepest meaning of noncombatant immunity" that it has this dual individual-collective nature. But in the just war literature that Walzer says "helps us understand the wrongfulness of terrorism (Walzer, 2006)," the phrase "noncombatant immunity" is synonymous with "the requirement of discrimination." But if noncombatant immunity has individual and collective dimensions, and the collective dimension includes territorial rights, then violations of collective territorial rights in war must count as violations of the requirement of discrimination. This is not only a novel view but one that dilutes the notion of discrimination and undermines the distinctiveness and moral force of the requirement.

Terrorism as it is normally understood is a crime of means. But as these passages show, Walzer thinks that it is also defined by its noninstrumental aims, which have as their object a devalued collective. Terrorism, he claims, is also a crime of ends: It aims at the expulsion, subordination, or annihilation of a people, a human community.

I think this is a mistake. Terrorism does not necessarily seek any particular end. It is a crime of means only.

Walzer may be right that terrorists often seek the expulsion, subjugation, or destruction of a group or collective. But this is contingent; it is not a necessary feature of terrorism. When terrorists do seek such ends, they are guilty of crimes of means and crimes of ends. But only the means are terrorist. The end they seek may actually be far worse than the terrorist means they employ. It is more seriously wrong to expel, subjugate, or annihilate an entire people than it is to kill a few as a means of influencing the others. But there are other names for these crimes of ends - for example, genocide. As Walzer notes, "terrorism" is not "the only negative term in our moral vocabulary (Walzer, 2006)."

Walzer seems implicitly to concede that terrorism is only a crime of means and does not necessarily seek to rid its perpetrators of the burden of coexistence with some other group when he observes that "if we name terrorists by their actions rather than their supposed goals, we are then free to support the goals - if we think them just - and even actively pursue them in non-terrorist ways." This might seem to presuppose that terrorist action can have goals that are limited and even just.

Yet his reference is to the 'supposed goals' of terrorists, implying that terrorists only profess to have limited or just goals when in fact their aims are always, to use his word, "totalizing." He considers possible examples of terrorist acts aimed at securing limited goals: Acts by the IRA and the nuclear bombings of Hiroshima and Nagasaki by the US. But he contends that, on reflection, these are not counterexamples to his view that terrorism 
is a crime of ends as well as means. The IRA, he concedes, did have limited goals, but its acts were not terrorist since they were, supposedly, discriminate. (It is odd, in the wake of $9 / 11$, to cite attacks on "buildings that symbolize the power structure" as discriminate or non-terrorist, but perhaps the suggestion that the occupants were 'mostly' given warning is sufficient to exempt most from the charge of terrorism.) But what if the IRA's acts had been flagrantly and persistently indiscriminate? Would members of the IRA still not have been terrorists because their goals were limited?

His response to the US bombings is different. These, he says, were terrorist at the time they were carried out because at that time the US did intend the devaluation and subjugation of the Japanese people. It is just that after the fact the US decided to settle for less. But, again, what if the US had not demanded unconditional surrender but had bombed Japanese cities in order to force a conditional surrender with guarantees of political and cultural independence for postwar Japan? Would the bombings then not have been terrorist acts, despite their killing vast numbers of innocent civilians as a means of coercing their government? I would see no reason in this case to withdraw the label.

It is not a factual truth that indiscriminate means cannot be used in the absence of "totalizing" ends. Nor is it a conceptual truth that indiscriminate means in the service of limited ends cannot be terrorist. Wrongs of means and wrongs of ends are distinct and ought not to be conflated. We can recognize both that terrorist acts wrong the collective of which the immediate victims are members and that acts that seek to expel a people from their homeland, subjugate them, or annihilate them are gravely wrong without claiming that all terrorist acts necessarily seek these egregiously wrongful ends.

\section{Reference}

Walzer, M. (2006). Terrorism and just war. Philosophia, 34:1 (present issue). 